\title{
Epigenetic regulation of asthma and allergic disease
}

\author{
Philippe Bégin and Kari C Nadeau*
}

\begin{abstract}
Epigenetics of asthma and allergic disease is a field that has expanded greatly in the last decade. Previously thought only in terms of cell differentiation, it is now evident the epigenetics regulate many processes. With $T$ cell activation, commitment toward an allergic phenotype is tightly regulated by DNA methylation and histone modifications at the Th2 locus control region. When normal epigenetic control is disturbed, either experimentally or by environmental exposures, Th1/Th2 balance can be affected. Epigenetic marks are not only transferred to daughter cells with cell replication but they can also be inherited through generations. In animal models, with constant environmental pressure, epigenetically determined phenotypes are amplified through generations and can last up to 2 generations after the environment is back to normal. In this review on the epigenetic regulation of asthma and allergic diseases we review basic epigenetic mechanisms and discuss the epigenetic control of Th2 cells. We then cover the transgenerational inheritance model of epigenetic traits and discuss how this could relate the amplification of asthma and allergic disease prevalence and severity through the last decades. Finally, we discuss recent epigenetic association studies for allergic phenotypes and related environmental risk factors as well as potential underlying mechanisms for these associations.
\end{abstract}

Keywords: Epigenetic, Asthma, Allergy, Atopy, Inheritance, Transgenerational, Methylation, Histone, Th2, Amplification hypothesis

\section{Introduction}

The term epigenetics was coined by C.H. Waddington in the 1950's to describe means in addition to genetics to explain cell differentiation [1]. The concept of epigenetics was initially limited to cell differentiation from pluripotent stem cells to unipotent well differentiated cells, but the modern definition of epigenetics has been broaden beyond differentiation to include non-sequence inheritance. Epigenetic mechanisms have been shown to regulate many genes including those involved in inflammation and the immune response and to ensure inheritance of phenotype with cell division $[2,3]$.

The purpose of this review is to provide allergy/immunology professionals and researchers with a broad, yet easyto-follow, review of the epigenetic regulation of asthma and allergic disease. The main focus will be on DNA methylation and histone modifications, their relevance in the process of allergic sensitization, their impact on

\footnotetext{
* Correspondence: knadeau@stanford.edu

Allergy, Immunology, and Rheumatology Division, Stanford University, 269 Campus Drive, Stanford, California, USA
}

disease heritability and association with environmental exposure and allergy phenotype. MicroRNA, which constitute a distinct epigenetic mechanism, are beyond the scope of this review. Their role in allergic disease has been reviewed recently elsewhere [4].

\section{The basics}

DNA methylation was the first epigenetic mechanism recognised and the one that is most extensively studied. De novo methylation occurs in response to various cellular stressors and signal by DNA methyltransferases (Dnmt3a and Dmnt3b) which add a methyl group to position 5 of cytosine residues at a CpG site (Figure 1). CpG sites are dinucleotides consisting of a cytosine and guanine (the "p" stands for the phosphodiester bond linking the 2 nucleotides) which occur throughout the genome but may be concentrated in clusters referred to as $\mathrm{CpG}$ islands found at important regulatory sites, such as promoter and enhancer regions [5]. CpG islands are defined as a region with 200 base pairs containing an observed-to-expected CPG ratio that is greater than 60 


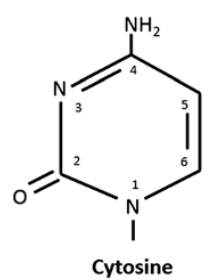<smiles></smiles><smiles>Nc1nc(=O)n(C(F)(F)F)cc1C=O</smiles>

Figure 1 Structure of methylcytosine and its by-products. $5-\mathrm{mC}=5^{\prime}$ methylcytosine; 5 -hmC $=5^{\prime}$-hydroxymethylcytosine; 5 - $\mathrm{fC}=5^{\prime}-\mathrm{formylcytosine;}$ 5-caC = 5'-carboxymethylcytosine.

[6,7]. In terminally differentiated cells up to $90 \%$ of genome CpG sites are methylated with most unmethylated $\mathrm{CpG}$ islands found in functionally active genes [5].

The palindromic nature of a CpG site is important as it ensures replication of the methylation pattern with each cell division [5]. With DNA replication, both separated strands of DNA will each carry one methylated cytosine to be used as a template for duplication (Figure 2). The resulting daughter DNA duplex strands will thus be hemi-methylated. This hemi-methylated DNA is recognized by a different DNA methyltransferase isoform (Dnmt1) which methylates CpG sites on the new strand using the old one as a template. This maintenance methylation ensures conservation of the methylation pattern during cell division.

Conversely, a CpG site can be demethylated by oxidation of the methyl group. Physiologically, this process is initiated by the enzyme Ten-eleven translocation (TET) dioxygenase which gives rise to 5-hydroxymethylcytosine and then to 5-formylcytosine and 5-carboxylcytosine [8]. These modified nucleic acids can also be generated, although far less efficiently, by radical reactions involving hydroxyl radical and one-electron oxidants. They are then excised by the DNA repair enzyme thymine DNA glycosylase and replaced by a normal cytosine [9].

The mechanism by which DNA methylation is associated with gene silencing is still not fully understood. Earlier studies reported that methylation could directly limit the access to transcription factors (TF) [10]. Although this is true for some TF, it is not an absolute rule as some TF have been shown to have greater specificity for methylated binding motifs [11]. Methylated DNA can also recruit methyl-CpG binding proteins which compete with TF for access to binding sites [12]. Some of these proteins, such as $\mathrm{MeCP} 2$, can further recruit histone modifying enzymes to add another level of epigenetic modifications (discussed below) [13]. However, the interaction between DNA methylation and other epigenetic mechanisms is not unidirectional as histone modifications can also affect DNA methylation [14]. In fact, studies in stem cells and thymocytes have shown chromatin inactivation by histone and chromatin modifying enzymes to precede de novo DNA methylation
A

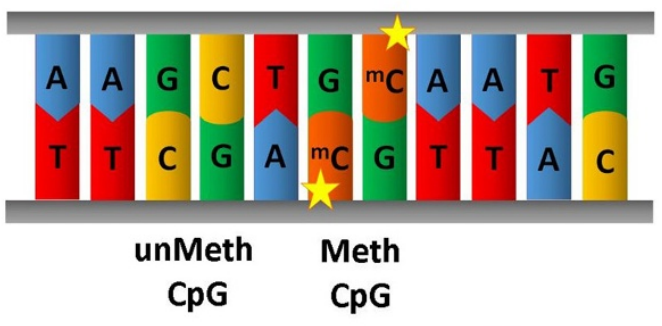

B
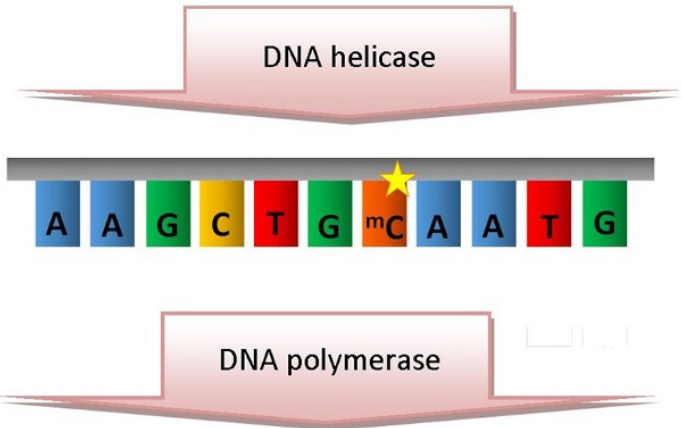

C
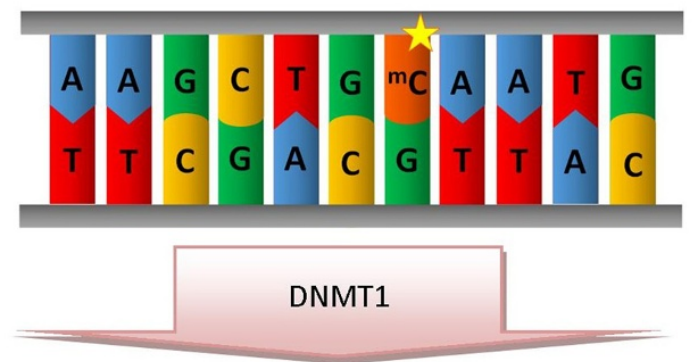

D

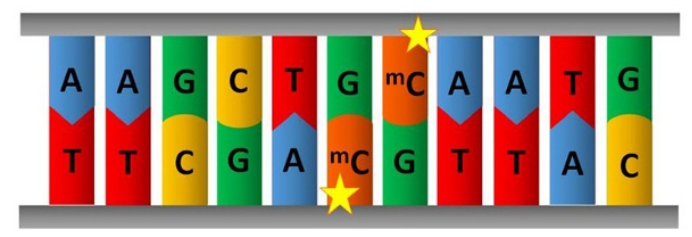

Figure 2 Replication of methylated DNA. The palindromic nature of $\mathrm{CpG}$ sites is key to their inheritance (A). With replication, each separated strand carries one methylated cytosine (B). The daughter hemi-methylated DNA (C) is recognised by DNMT isoform 1 which methylates CpG sites on the new strand using the old one as a template (D). 
during progressive epigenetic silencing [15-17]. Regardless of its underlying mechanism, DNA methylation is important in itself and should not be viewed as an epiphenomenon of other epigenetic mechanism as DNMT mutants display a multitude of defects, including aberrant gene expression, activation of mobile DNA elements and reduced genome stability [18].

Chromatin, the complex of DNA and nucleic proteins in the nucleus, is another central target of epigenetic modifications. Transcriptionally inactive heterochromatin is packed densely whereas active euchromatin is less condensed (Figure 3). The core component of chromatin is the histone octamer which organises DNA in structural units called nucleosomes [18]. The histone octamer consists of 2 dimers of core histones $\mathrm{H} 2 \mathrm{~A}$ and $\mathrm{H} 2 \mathrm{~B}$ and 2 dimers of core histones $\mathrm{H} 3$ and $\mathrm{H} 4$. Chromatin remodelling is a fundamental mechanism for establishing somatic cell memory of gene expression pattern. It is a dynamic process which is regulated by histones and ATP-dependent chromatin remodeling complexes which either move, eject or restructure nucleosomes. The "open" or "closed" state of the chromatin near a particular gene can be revealed by examining DNA sensitivity to the enzyme DNAse I by way of a procedure known as a DNAse sensitivity assay. This technique is based on the fact that DNAse I degrades open DNA more quickly than closed DNA, hence the term DNAse I hypersensitivity site (DHS) [19].

Core histones have long N-terminal tails protruding from the nucleosome which can undergo posttranslational modifications that alter their interaction with DNA and nuclear proteins. The standard way of reporting those modifications is by naming the histone, followed by the amino acid, and the modification. For example, H3K4me1 would denote single methylation (me1) of lysine $4(\mathrm{k} 4)$ on histone 3 (H3). Research has shown a strong relation between covalent histone modifications and gene expression [18]. As a general rule, histone acetylation or phosphorylation are associated with an active state. Histone methylation, on the other hand, appears to have diverse function in the control of gene activity, depending on the amino acid and the number of methyl- groups added. The nature and combination of these changes determine the extent of expression, with those highly expressed genes associated with greater permissive histone modifications and those less frequently transcribed ones associated with repressive changes and more tightly packaged chromatin, although the relationship between gene expression status and histone modification is not absolute [20]. In addition to influencing chromatin structure, recruitment of chromatinremodelling complexes by covalently modified amino acid on histone tails may also help target gene locus for preinitiation of transcription gene [21,22]. The addition or removal of the various chemical elements on histones is catalyzed by histone modifying complexes such as histone acetyl transferase (HAT) and histone deactetylase (HDAC) which add and remove acetyl- groups on histone residues, respectively.

\section{Epigenetic control of $\mathrm{T}$ cell phenotype} Th2 differentiation

While epigenetic changes have been coined as the hallmark of cell differentiation, their importance in other

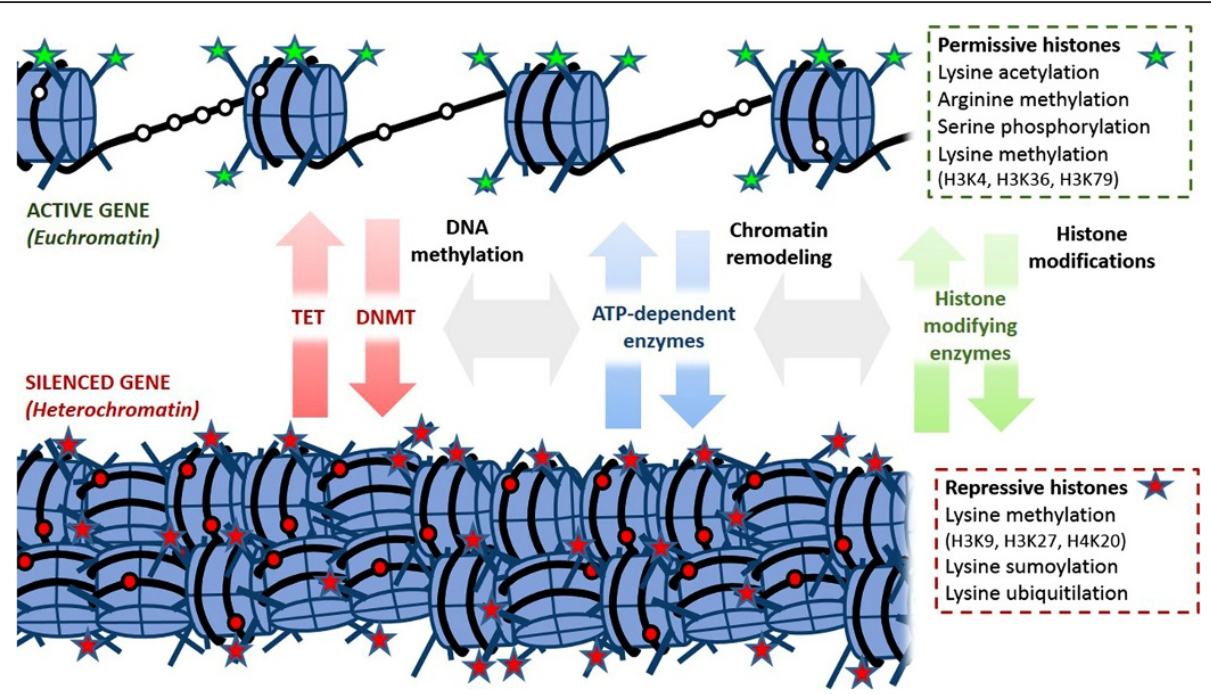

Figure 3 Euchromatin and heterochromatin. Unmethylated CpG islands (blank circles), permissive histone modifications (green stars) and loose chromatin structure promote gene transcription in the euchromatin state. Conversely, DNA methylation (red circles), repressive histone modifications (red stars) and condensed structure prevent transcription in the heterochromatin state. Although governed by distinct enzymes, cooperativity and interaction between the different epigenetic modifications provide a self-reinforcing mechanism for epigenetic regulation. TET=Ten-eleven translocation dioxygenase; DNMT=DNA methyltransferase. 
processes is now coming to light. Of note, T cell activation and skewing, which could be viewed as a certain type of cell differentiation, is governed in great parts by epigenetic changes which insure that the clone of a $\mathrm{T}$ cell will retain its phenotype (Th2, Th1 or otherwise) [23].

Th2 skewing is triggered by simultaneous TCR and IL4 receptor activation, which leads to the phosphorylation of STAT6 and expression of Th2 master regulator GATA-3 and Th2 signature cytokines, including IL-4. Th1 differentiation is similarly triggered by simultaneous TCR and IL-12 receptor activation, phosphorylation of STAT4 and expression of Th1 master regulator TBET and Th1 signature cytokine INF- $\gamma$, with silencing of Th2 cytokines.

In resting CD4 $\mathrm{T}$ cells, both $\mathrm{IL}-4$ and IFN-g genes are methylated [24]. Upon allergenic sensitization, the IL-4 promoter in allergen-specific $\mathrm{T}$ cells is demethylated, the extent of which correlates with IL-4 expression [24]. The IL-4 locus of Th2 cells is also marked with permissive histone modifications H3K4me which are absent in Th1 or naïve T cells [25]. Similar modifications are found at the IFN- $\gamma$ locus in Th1 cells or the IL-17 locus in Th17 cells.

The main Th2 genes are positioned in the Th2 locus control region (LCR) on chromosome 5 which forms a chromatin hub that interacts with GATA-3 (Figure 4) [23]. GATA-3 then interacts with HAT enzyme p300 and with chromatin remodeling complex component Chd to induce permissive histone and chromatin changes at the Th2 LCR [26]. The GATA-3/Chd complex also binds HDAC to repress the tbx 21 locus encoding TBET, the master regulator of Th1 differentiation which activates Th1 genes and suppresses Th2 genes [26], and recruits the $\mathrm{H} 3 \mathrm{k} 27 \mathrm{~m} 3$ methyltransferase EZH2 to the IFN-g locus, causing its inhibition [27]. Further suppression of Th1 cytokines is achieved by the increase of their DNA methylation from naïve state [28]. In Th1 cells, STAT4 and TBET have been shown to exert similar but inverse influence on IFN-g and Th2 genes epigenetics to promote Th1 skewing [29].

The exact mechanism of DNA demethylation of Th2 genes is still incompletely understood, possibly due to the only recent discovery of the TET enzymes which are responsible for physiological DNA demethylation. In a mouse study, GATA-3 was insufficient to induce DNA demethylation of the RAD50 DHS site 7 in the Th2 LCR, although the process was shown to be dependent on STAT6 [30]. Interestingly, knocking-out RAD50 DHS site 6 prevented DNA methylation of IL-4, IL-5 and IL13 , suggesting an interdependence between those genes and an important role for the chromatin hub structure of the Th2 LCR (Figure 4) [31].

Interestingly, the GATA-3 promoter has been shown to keep its repressive histone modification despite TH2 activation and present a bivalent state with both repressive and activating histone modification [25]. This suggests an important role for positive feedback to additionally insure its stable expression, with GATA-3 positive binding to its regulatory elements. It is also worth noting that the main anti-Th1 effect of GATA-3 is exerted through direct inhibition of the IL-12/STAT4 and RUNX pathways [23].

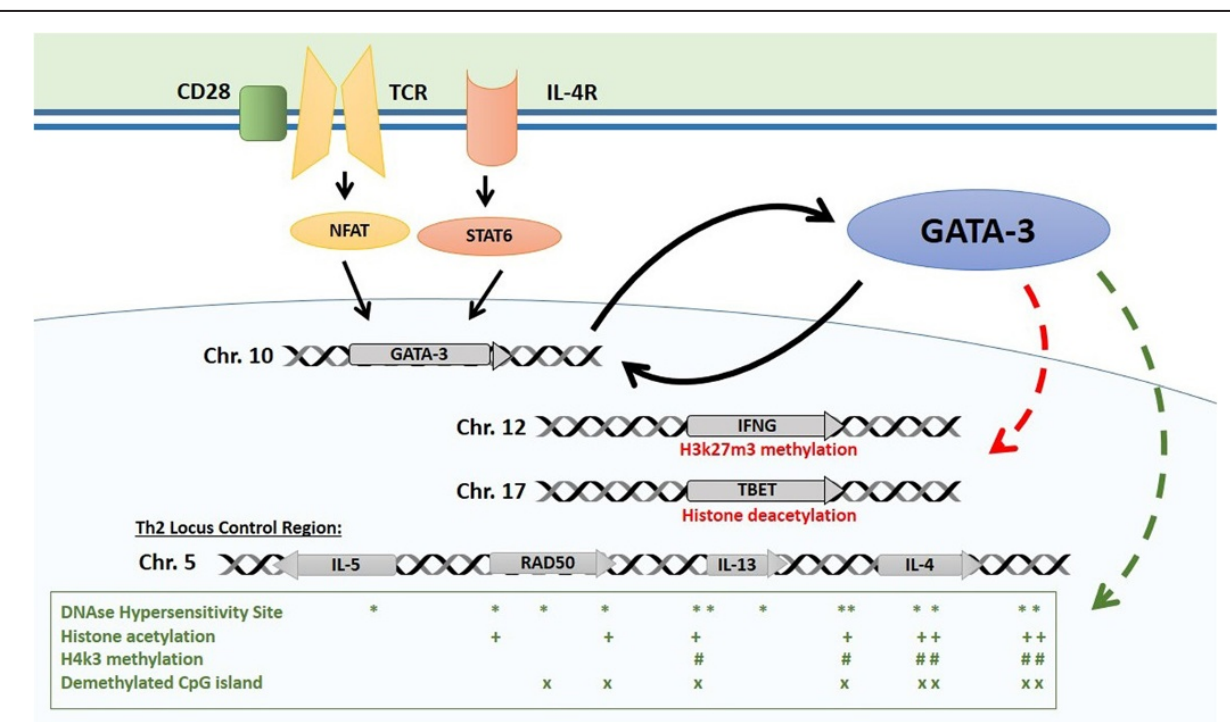

Figure 4 Epigenetic control of the Th2 locus. Master regulator GATA-3 is induced by TCR and IL-4 receptor activation and maintains its own expression with a positive feedback mechanism. GATA-3 induces repressive histone modifications at Th1 loci (TBET, IFNG). It interacts with HAT enzyme p300 with chromatin remodeling complex component Chd to induce permissive histone and chromatin changes at the Th2 LCR. Distribution of main epigenetic marks at the Th2 LCR [23] are presented in the lower box. 


\section{Establishment of $\mathrm{T}$ regulatory phenotype}

$\mathrm{T}$ regulatory cells are a subset of $\mathrm{T}$ cells which suppress the inflammatory response and thus play an important role in immune tolerance to self and exogenous antigens. Their function and number in tissue has been shown to inversely correlate with allergic phenotypes and their importance in allergic disease has been well described [32].

FOXP3 is the master regulator for regulatory $\mathrm{T}$ cells (Treg) [33] which can be divided in two subsets based on their origin: Tregs of thymic origin (tTreg), which were previously referred to as natural Tregs and peripherallyderived Treg (pTregs). FOXP3 expression is controlled by proximal promoter and intronic regulatory elements designated as conserved non coding sequences (CNS1-3) which are highly conserved between species.

In the thymus, tTregs are induced by TCR engagement with self-peptide major histocompatibility complex with specific strength and duration. The subsequent NF-kB signaling induces permissive histone modification (H3K4me1) at the CNS3 and potentially initiates chromatin remodeling in the FOXP3 locus through the c-Rel subunit [34]. In parallel, cAMP response element-binding protein (CREB) binds to the CNS2 element, which inversely correlates with the methylation status of $\mathrm{CpG}$ islands [35]. DNA demethylation of the CNS2, also called the Treg-specific demethylated region (TSDR) is a major event in tTreg differentiation and carries an important function in FOXP3 stabilizing FOXP3 expression [36]. CNS2 is the site at which FOXP3 binds to its own gene to maintain expression in a positive feedback mechanism allowing for a persistent phenotype and suppressive function. FOXP3 induces the expression of IL-2 receptor CD25, which activation phosphorylates STAT5 which binds the promoter and CNS2 independently of methylation status providing an additional positive feedback mechanism [37].

Besides Tregs, activated $\mathrm{T}$ cells also express FOXP3 upon TCR engagement [38]. However, this expression is only transient as the CNS2 remains methylated. In fact, when comparing tTregs to FOXP3+ activated effector $\mathrm{T}$ cells there are hundreds of loci throughout the genome which show demethylation and correspond to binding sites for FOXP3 [39]. These methylation changes are not induced by FOXP3 but rather allow FOXP3 to access its targets and exert its function. The lack of demethylation of these loci could explain the difference in function despite the expression of FOXP3 in activated T cells.

In contrast to thymic-derived Tregs, generation of Tregs from peripheral naïve $T$ cells is favored by suboptimal TCR stimulation in the presence of TGF- $\beta$ [40]. TGF- $\beta$ promotes FOXP3 transcription in peripheral CD4 T cells through binding of SMAD3 at CNS1 [41]. A FOXP3CNS1-deficient mice mouse has shown that CNS1 is critical for FOXP3 induction in peripheral CD4 $\mathrm{T}$ cells but not in thymocytes. Interestingly, those mice lacked the self-reactive auto-immune manifestations observed in FOXP3 deficient scrufy mice, but had maternal-fetal conflict and inflammatory disease at the mucosal interface, suggesting a specific role for $\mathrm{p}$ Tregs in acquired tolerance to exogenous antigens [42]. The generation of TGF- $\beta$-induced Tregs can be augmented by the addition of retinoic acid, which has been shown to induce histone acetylation at the CNS1 region [43]. While in vitro differentiated Treg cells appear to lack TSDR demethylation, in vivo pTregs gradually demethylate the TSDR which could contribute to phenotype stability [44].

\section{Inheritance of epigenetic traits}

Development of allergy and asthma is determined by interplay between environmental and inherited factors, the later accounting for over half of the risk [45]. Interestingly, this is in high contrast with the low fraction of variance in asthma prevalence (4\%) that can be accounted for by genetic loci in a large-scale genome wide association study $[46,47]$. This missing heritability could be due in part to the difficulty of accounting for rare polymorphisms with a high penetrance in some families (private mutations) but it also raises the possibility of non-genetic means of inheritance [46].

Genetics also fail to explain the sudden rise in allergies and asthma as even with significant selection pressure, any change in population genetics would necessitate multiple generations to occur. Epigenetic changes on the other hand can be induced much more rapidly with various environmental exposures and, like with genetics, these changes can be passed down from parents to offspring. There are several ways in which epigenetics can influence phenotype inheritance, including gene imprinting, in utero modifications and transgenerational inheritance.

\section{Parental imprinting and maternal influence}

Asthma and atopy are complex genetic traits meaning that the phenotype is the result of the interaction of multiple genes each with their own Mendelian pattern of inheritance. The expected result is that no clear pattern of inheritance would be discernable, with risk from both parents being very similar overall. In reality, the risk for allergy and asthma inherited from the mother is up to 5 fold greater than the paternal risk [48-51].

The discrepancy in parental risk could be explained in part by parental imprinting. Parental imprinting is a process by which some genes are epigenetically silenced during gametogenesis in a parent-of-origin-specific manner, which results in only one allele being expressed for the imprinted loci. The best example probably consists of polymorphisms of FceR1- $\beta$ which are only associated with atopy when the risk allele is inherited from the mother in multiple cohorts $[49,52,53]$. 
A more recent study showed that maternal but not paternal atopy predicted the expression profile of 18 cytokines and chemokine in the airway mucosal fluid of newborns [54]. However, it is unclear whether this is the result of true genomic imprinting or from a direct modification of the foetal immune system by the mother's atopic phenotype in utero. Animal studies have shown that challenging previously sensitized mice to ovalbumin during pregnancy resulted in an increased allergic phenotype in offsprings [55]. Transferring $\mathrm{T}$ cells from sensitized to naïve pregnant mice had the same effect, suggesting this in utero influence was mediated at least in part by the maternal immune system after conception [56]. In humans, one groups has evaluated the methylome of over 300 pregnant women using a high throughput DNA methylation analysis and found that a score of differentially methylated regions better predicted atopic disease in children than clinical data [57]. The same group is currently looking at the correlation of DNA methylation in the neonates cord blood to better understand the mechanisms involved.

\section{Transgenerational inheritance}

It has been well described that through development, with the shift from pluripotent stem cells to well differentiated specialized cell types, chromatin becomes increasingly repressed by histone modifications and less activated by permissive histones [58]. However, while it was originally thought that epigenetic marks were completely erased from germline upon conception, this concept has been disproved over a decade ago $[59,60]$. It is now evident that epigenetic changes induced by environmental exposure may alter the epigenome of the germline and persist through generations.

In their canonical experiment with the agouti mouse model, Morgan et al., fed mice with a methyl-donor rich diet that favored the methylation of the agouti gene, which codes for signalling peptide in mice, which affects coat colour pigmentation. Not only did this influence their immediate offspring's fur color, but throughout five generations with the exact same diet, the fur coat would get darker and darker showing transgenerational transmission of the phenotype, which is not only inherited but augmented [60]. The experiment was repeated recently by Cropley and colleagues who studied the effect of stopping the methyl donor rich diet after 5 generations [61]. Interestingly they found that the following generation $\left(F_{6}\right)$, which was not exposed to the diet, actually exhibited a further increase in fur pigmentation, with normal color returning only with the second generation off therapy $\left(\mathrm{F}_{7}\right)$. Mice from the fifth generation had been weaned and put on normal control diet before mating, showing the effect of the diet did not take place in utero. Rather, it suggests that germ cells exposed to excess methyl donors within the developing $\mathrm{F}_{5}$ females retained a memory of the methyl donor effect, manifested in $\mathrm{F}_{6}$ mice [61].

In utero diet supplementation with methyl donors has similarly been shown to increase allergic disease in a mouse model [62]. The F1 progeny exposed to an in utero diet supplemented with methyl donors demonstrated enhanced cardinal features of allergic airway disease, including airway hyperreactivity, lung lavage eosinophilia and IL-13, higher concentrations of serum IgE as well as change in splenocyte phenotype compared to controls on normal diet. More importantly, these traits were passed down transgenerationally, although somewhat less robustly, in F2 "grand-children" mice which did not have in utero supplementation. In human, transgenerational inheritance is exemplified by the effects of tobacco, which may last for 2 generations. Li et al. compared 338 children diagnosed with asthma in their first 5 years of life to 570 countermatched controls and found that a child whose maternal grandmother smoked during pregnancy had double the chance of developing asthma [63]. This risk was even greater if the mother also smoked during pregnancy $(\mathrm{OR}=2.6$, compared to 1.8 if she did not) supporting the epigenetic transgenerational model in which persistent exposure leads to inheritance and augmentation of the phenotype. However, this association was only replicated for paternal grandmother smoking (which had not been investigated in the former report) in a recent study [64]. The reason for these discordant results is unclear. It could relate to differences in study populations. The first study included children from a southern California cohort [65] (66\% white, relatively high levels of air pollution) with slightly earlier diagnosis of asthma (before 5 years) while the second one, from Avon, UK (96\% white), included subjects with diagnosis before 7 years of age.

Transgenerational inheritance of epigenetic traits is extremely interesting from an epidemiologic point of view as it provides a new hypothesis for the persistently increasing prevalence of allergy and related disorders. If the recent increase had been due to a change in environment, prevalence should have increased at once and remained stable as long as this environment remained the same. However, if the new environment induces epigenetic changes, a transgenerational amplification of the atopic phenotype would be expected even with stable exposure (Figure 5). Furthermore, according to this hypothesis, it would be expected that the benefit of some interventions to prevent allergies (such as pro- and prebiotics) could take a full generation before reaching their full effect, hence possibly the somewhat disappointing results so far [66].

\section{Association studies in asthma and allergy}

At this stage, most of the epigenetic literature on asthma and allergy consists of association studies [67-88]. As with genetic association studies, both candidate gene and 

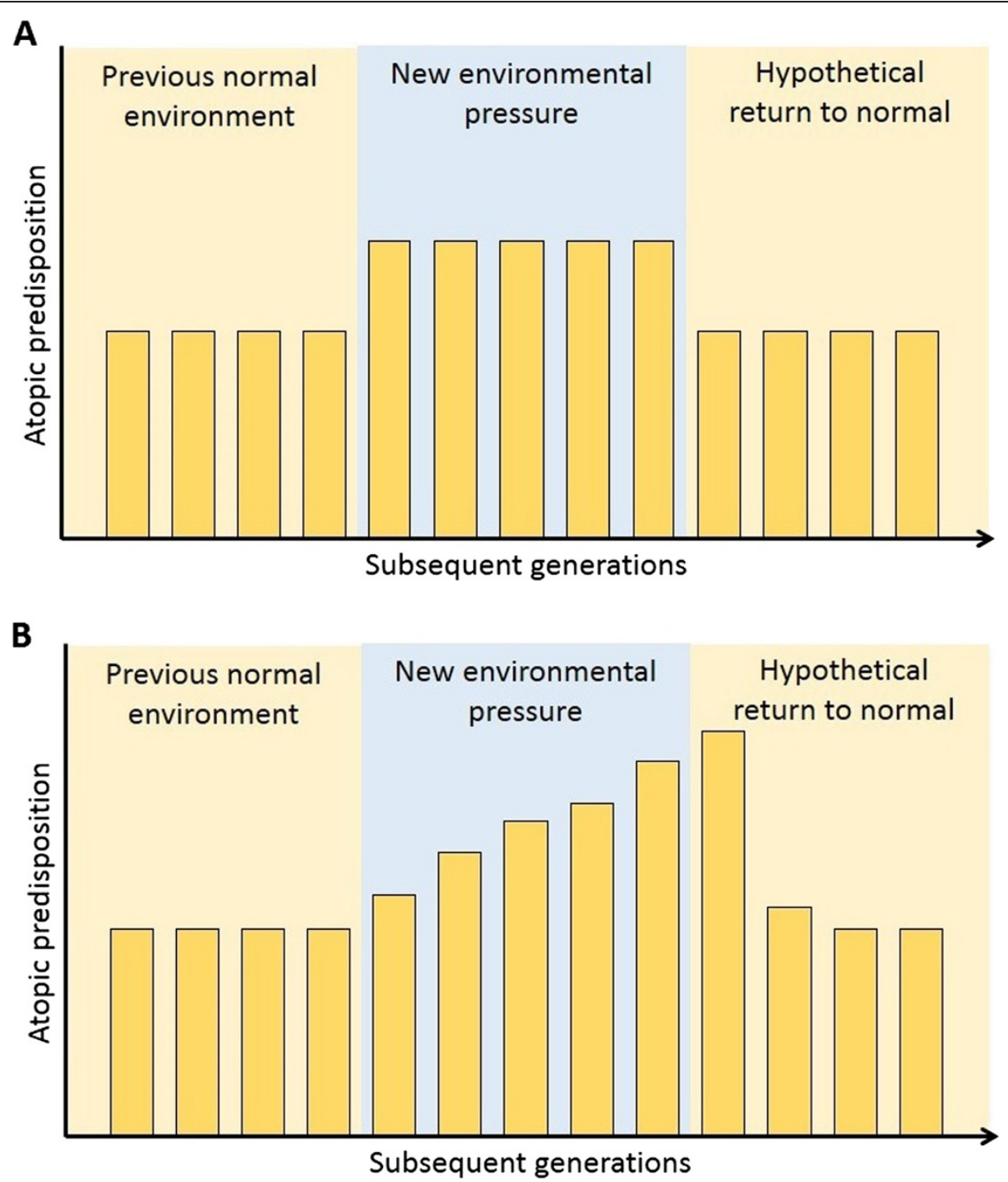

Figure $\mathbf{5}$ Transgenerational amplification hypothesis. Panel A depicts a purely environmental model for the rise of atopic disease, in which a change in environment increases baseline genetic risk for the disease. Panel $\mathbf{B}$ depicts an epigenetic transgenerational inheritance model, in which a persistent change in environment does not only increase baseline risk but induces transmittable epigenetic changes leading to amplification of the phenotype with every subsequent generation. Return to a normal environment, will lead to resolution of the phenotype but only after 2 generations.

genome-wide approaches are used. Candidate gene approach has the benefit of allowing the specific study of a certain number of particularly relevant genes. Its main disadvantage is the fact that it relies on the investigators hypothesis as to which gene(s) to study. Genome-wide approaches do not have this limitation. However, the amount of analysed data is so great that some relevant but weakly associated loci may be lost after statistical corrections.

Figure 6 provides a list of selected loci that have been reported to be associated with allergic phenotypes and/or environmental risk factors. Association studies are extremely helpful to provide a description of the epigenetic landscape of a given phenotype, which can lead to the identification of potential biomarkers or targets for therapy. However, they are not sufficient to conclude causality, especially when dealing with a mixed cell population (biopsy or whole PBMCs). Since different differentiated cell types exhibit a different methylation pattern (i.e. Th2 vs Th1 vs Treg cells), changes in the proportion of these subsets will directly affect the methylation pattern of the overall population. Thus, finding more demethylation of the Th2 LCR genes (IL-4, IL-13) in PBMCs from atopic individuals may be only a reflection of the larger proportion of Th2 cells in those individuals, and not the cause of it.

An exciting aspect of epigenetics is that it sheds a new light on previous genetic association studies. Since epigenetic marks have the potential to silence a gene, it is to be expected that it can modulate the effect of an 


\begin{tabular}{|c|}
\hline $\begin{array}{l}\text { Associations with phenotype } \\
\text { Asthma }\end{array}$ \\
\hline Immune response: FOXP3(67), INF-g(67), STAT5A(68), CRIP1(68), IL-4R(69) \\
\hline NO synthesis: $A R G 2(70)$ \\
\hline Lipid pathway: ALOX12(71), ASCL3(72) \\
\hline Pharmacologic receptor: ADRB2(73) \\
\hline Atopy \\
\hline Immune response: $T L S P(74)$ \\
\hline Lipid pathway: PTGDR(75) \\
\hline Xenobiotics: CYP26A1(76) \\
\hline Various: 58 genes (77) \\
\hline Associations with environmental exposure \\
\hline Tobacco smoke \\
\hline Immune response: $T G F B 3(78)$ \\
\hline Xenobiotic metabolism: $A H R R(79)$, CYP1A1(79) \\
\hline Signaling: NPSR1(80), GFI1(79), PTPRO(78) \\
\hline Oncogenes: $\operatorname{SPDEF}(78), \operatorname{SNCG}(78), \operatorname{AXL}(78), \operatorname{MET}(78), \operatorname{NBL1}(78), \operatorname{KLK11}(78)$ \\
\hline Farming \\
\hline Immune response: $\operatorname{STAT6(82),}$ RAD50(82), IL13(82), IL4(82), CD14(81) \\
\hline Sphyngolipid synthesis: ORMDL1(82) \\
\hline Pollution \\
\hline Immune response: FOXP3(83), IFN-g(83), CTLA-4(84), IL-10(84), IL1-R2(84), IFN-g(85) \\
\hline NO synthesis: $\operatorname{NOS} 2 A(86), \operatorname{NOS} 3(86)$, iNOS(87) \\
\hline Lipid Pathway: ASCL3(72) \\
\hline Xenobiotics metabolism: CYPBRD1(84) \\
\hline Signaling:CLK2(84), MAP3K7(84), PIK3CG(84) \\
\hline DNA-binding: ZNF445(84), PHF20L1(84), TRPS1(84) \\
\hline Pet keeping \\
\hline Immune response: $C D 14(88)$ \\
\hline
\end{tabular}

Figure 6 Loci identified from previous DNA methylation association studies for asthma, atopy and related exposures.

underlying polymorphism on disease risk. For example, IL-4R single-nucleotide polymorphism (SNP) rs3024685, which is not associated with asthma on its own, carries a significant risk for the disease when controlled for IL4-R methylation [69].

Similarly, the 17q12-21 which carries 2 polymorphisms associated with maternally inherited risk for asthma was found to be highly methylated in adult males [89]. In fact, epigenetic changes can alter the effect of gene polymorphisms over time. The decreasing effect of CD14 polymorphism on soluble CD14 levels has been shown to be paralleled by small but significant increases in CD14 methylation from 2 to 10 years of age [90].

Genetic polymorphisms can also in turn affect epigenetics regulation of gene expression at a given locus [71,75]. Morales and colleagues showed that hypomethylation of CpG site in the arachidonate 12-lipoxygenase (ALOX12) gene correlated with wheezing in two Spanish cohorts. In both cohorts, they found that the extent of hypomethylation correlated with the genotype for haplotype-tagging single nucleotide polymorphism (SNP) rs312466. In the Menorca cohort for example, subjects with G/G genotype had a $25 \%$ genome methylation at CpG site E85, compared to $15 \%$ and $7 \%$ methylation for genotypes G/A and A/A, respectively) [71]. Recently, North and colleagues found that DNA methylation of the Ephrin-B3 gene (EFNB3), a transmembrane ligand for receptor tyrosine kinases involved in bidirectional signaling, correlated with total symptom scores recorded after exposure to grass for two days in an Environmental Exposure Unit [91]. They also identified two SNPs which influenced on methylation status. One of those, rs3744262 changes a cytosine for a thymine on a CpG site (CpG-SNP) and therefore directly impacted on its methylation. These studies show how polymorphisms and epigenetic regulations are interrelated and how future studies should be structured to examine these interactions.

\section{Potential underlying mechanisms}

Although our understanding is still superficial, there is an increasing amount of literature looking into the mechanisms by which allergic phenotypes and environmental exposures could be associated with specific epigenetic changes.

In lung biopsies, the HDAC: HAT ratio has been shown to be lower in asthmatic samples and to correct with treatment [92-96]. This is significant as endogenous HDAC activity may play a crucial role in maintaining the balance of pre-established Th1-like and Th2-like responses. When their endogenous HDAC activity is inhibited, ex vivo memory $\mathrm{T}$ cells show an increase in Th2-associated recall response (IL-13, IL-5) and reduction in Th1- (IFN- $\gamma$, CXCL10) or Tr1-associated (IL-10) recall response, shifting the Th1:Th2 ratios by 3 -fold to 8 -fold [97]. However, the relation between HDAC/HAT activity and allergic inflammation is not that simple. Inhibition HDAC may also increase the suppressive function of FOXP3+ Tregs ex vivo [98] and the induction of pTregs by the metabolites 
of commensal bacterias has been shown to relate to their HDAC inhibitory property which decreases proinflammatory cytokine expression in dendritic cell [99]. The transmaternal asthma protection provided by the farm-derived gram-negative bacterium Acinetobacter lwoffii F78 was associated with an increase in permissive $\mathrm{H} 4$ acetylation of the INF- $\gamma$ locus and this protection was abolished when mice were treated with an HAT inhibitor [100]. It is important to point out that histones are not the only targets of acetylation. Multiple cellular proteins with important functions are also regulated by acetylation and will be affected by changes of HDAC/HAT activities. This includes signal transducers and nuclear factors that are relevant to the immune response such as GATA-3 and FOXP3 [101]. More specifically, mice studies have shown that optimal Treg function requires acetylation of several lysines in the forkhead domain of Foxp3 which enhance binding to the Il2 promoter and suppress endogenous IL-2 production $[102,103]$. In the end, the question remains as to what causes this change in HDAC/HAT activity in the first place in atopic subjects.

Environmental tobacco smoke supresses the expression and activity of HDAC2 and HDAC3 [104,105]. Exposure to tobacco smoke has also been shown to alter the expression of dnmt1 and dnmt3b [106]. Both tobacco smoke and pollution induce oxidative stress which are thought to favour the demethylation process, as well as to cause lesions to DNA which prevent binding of Dnmt, resulting in a non-specific decrease in methylation across the genome [107-109]. This non-specific interference with the epigenetic process could potentially have a major impact on a concomitant immune response to an allergen given the complex epigenetic control involved in mounting such a response.

Although a diet rich in methyl-donor nutrients has been shown to promote DNA methylation and to induce an allergic phenotype in mice, the same has yet to be shown for humans [62]. Maternal intake of folic acid (a methyl donor) during pregnancy does not influence risk for atopy [110], asthma [111] or food allergy [112]. Whether the previously reported protective effect of antioxidant supplement can be related to an effect on DNA demethylation is still undetermined [113-116].

\section{Conclusion}

Epigenetics is an exciting new field in allergy and asthma research that has strongly evolved in the last decade. Recent studies shed a new light on the pathogenesis of this complex group of disease, not only with regards to geneenvironment interaction but also with regards to the model of inheritance and its epidemiological implications. The field is still at its infancy stage and more work needs to be done to dissect the epigenome of asthma and allergy and to better understand its underlying mechanisms.

\section{Abbreviations}

DNMT: DNA methyltransferase; HAT: Histone acetyltransferase; HDAC: Histone deacetylase; TET: Ten-eleven translocation; DHS: DNAse I Hypersensitivity site; TSDR: Treg-specific demethylated region; LCR: Locus control Region; TCR: T cell receptor; SNP: Single nucleotide polymorphism.

\section{Competing interests}

The authors declare that they have no competing interests.

\section{Authors' contributions}

PB performed litterature review and wrote the manuscript. NK reviewed the manuscript. Both authors read and approved the manuscript.

\section{Acknowledgment}

The authors would like to aknowledge Dr Sharon Chinthrajah for careful proof reading of the manuscript. Philippe Bégin MD, FRCPC is supported by AllerGen NCE Inc. (the Allergy, Gene and Environment Network), a member of the Networks of Centre of Excellence Canada program.

Received: 10 January 2014 Accepted: 18 May 2014

Published: 28 May 2014

\section{References}

1. Baedke J: The epigenetic landscape in the course of time: Conrad Hal Waddington's methodological impact on the life sciences. Stud Hist Phil Biol Biomed Sci 2013, 44(4):756-773. PubMed PMID: 23932231.

2. Barnes PJ: Targeting the epigenome in the treatment of asthma and chronic obstructive pulmonary disease. Proc Am Thorac Soc 2009, 6(8):693-696. PubMed PMID: 20008877.

3. Suarez-Alvarez B, Baragano Raneros A, Ortega F, Lopez-Larrea C: Epigenetic modulation of the immune function: a potential target for tolerance. Epigenetics 2013, 8(7):694-702. PubMed PMID: 23803720. Pubmed Central PMCID: 3781188

4. Lu TX, Rothenberg ME: Diagnostic, functional, and therapeutic roles of microRNA in allergic diseases. J Allergy 2013, 132(1):3-13. quiz 4. PubMed PMID: 23735656. Pubmed Central PMCID: 3737592.

5. Wu SC, Zhang Y: Active DNA demethylation: many roads lead to Rome. Nat Rev Mol Cell Biol 2010, 11(9):607-620. PubMed PMID: 20683471. Pubmed Central PMCID: 3711520

6. Gardiner-Garden M, Frommer M: $\mathrm{CpG}$ islands in vertebrate genomes. J Mol Biol 1987, 196(2):261-282. PubMed PMID: 3656447.

7. Saxonov S, Berg P, Brutlag DL: A genome-wide analysis of CpG dinucleotides in the human genome distinguishes two distinct classes of promoters. Proc Natl Acad Sci U S A 2006, 103(5):1412-1417. PubMed PMID: 16432200. Pubmed Central PMCID: 1345710.

8. Cadet J, Wagner JR: TET enzymatic oxidation of 5-methylcytosine, 5-hydroxymethylcytosine and 5-formylcytosine. Mutat Res 2013, 764-765:18-35. PubMed PMID: 24045206.

9. Hashimoto H, Hong S, Bhagwat AS, Zhang $X$, Cheng X: Excision of 5-hydroxymethyluracil and 5-carboxylcytosine by the thymine DNA glycosylase domain: its structural basis and implications for active DNA demethylation. Nucleic Acids Res 2012, 40(20):10203-10214. PubMed PMID: 22962365. Pubmed Central PMCID: 3488261

10. Adams RL: DNA methylation. The effect of minor bases on DNA-protein interactions. Biochem J 1990, 265(2):309-320. PubMed PMID: 2405840. Pubmed Central PMCID: 1136889

11. Hu S, Wan J, Su Y, Song Q, Zeng Y, Nguyen HN, Shin J, Cox E, Rho HS, Woodard C, Xia S, Liu S, Lyu H, Ming GL, Wade H, Song H, Qian J, Zhu H: DNA methylation presents distinct binding sites for human transcription factors. elife 2013, 2:e00726. PubMed PMID: 24015356. Pubmed Central PMCID: 3762332

12. Boyes J, Bird A: DNA methylation inhibits transcription indirectly via a methyl-CpG binding protein. Cell 1991, 64(6):1123-1134. PubMed PMID: 2004419.

13. Nan X, Ng HH, Johnson CA, Laherty CD, Turner BM, Eisenman RN, Bird A: Transcriptional repression by the methyl-CpG-binding protein MeCP2 involves a histone deacetylase complex. Nature 1998, 393(6683):386-389. PubMed PMID: 9620804

14. Murr R: Interplay between different epigenetic modifications and mechanisms. Adv Genet 2010, 70:101-141. PubMed PMID: 20920747. 
15. Su RC, Brown KE, Saaber S, Fisher AG, Merkenschlager M, Smale ST: Dynamic assembly of silent chromatin during thymocyte maturation. Nat Genet 2004, 36(5):502-506. PubMed PMID: 15098035.

16. Su RC, Sridharan R, Smale ST: Assembly of silent chromatin during thymocyte development. Semin Immunol 2005, 17(2):129-140. PubMed PMID: 15737574

17. Cedar $H$, Bergman $Y$ : Linking DNA methylation and histone modification: patterns and paradigms. Nat Rev Genet 2009, 10(5):295-304. PubMed PMID: 19308066

18. Weissmann F, Lyko F: Cooperative interactions between epigenetic modifications and their function in the regulation of chromosome architecture. BioEssays 2003, 25(8):792-797. PubMed PMID: 12879449.

19. Gregory RI, Khosla S, Feil R: Probing chromatin structure with nuclease sensitivity assays. Methods Mol Biol 2001, 181:269-284. PubMed PMID: 12843457

20. Wang Z, Zang C, Rosenfeld JA, Schones DE, Barski A, Cuddapah S, Cui K, Roh TY, Peng W, Zhang MQ, Zhao K: Combinatorial patterns of histone acetylations and methylations in the human genome. Nat Genet 2008 40(7):897-903. PubMed PMID: 18552846. Pubmed Central PMCID: 2769248

21. Dey A, Chitsaz F, Abbasi A, Misteli T, Ozato K: The double bromodomain protein Brd4 binds to acetylated chromatin during interphase and mitosis. Proc Natl Acad Sci U S A 2003, 100(15):8758-8763. PubMed PMID: 12840145. Pubmed Central PMCID: 166386.

22. Zeng L, Zhang Q, Li S, Plotnikov AN, Walsh MJ, Zhou MM: Mechanism and regulation of acetylated histone binding by the tandem PHD finger of DPF3b. Nature 2010, 466(7303):258-262. PubMed PMID: 20613843. Pubmed Central PMCID: 2901902

23. Zeng WP: 'All things considered': transcriptional regulation of T helper type 2 cell differentiation from precursor to effector activation. Immunology 2013, 140(1):31-38. PubMed PMID: 23668241. Pubmed Central PMCID: 3809703

24. Kwon NH, Kim JS, Lee JY, Oh MJ, Choi DC: DNA methylation and the expression of IL-4 and IFN-gamma promoter genes in patients with bronchial asthma. J Clin Immunol 2008, 28(2):139-146. PubMed PMID: 18004650

25. Wei G, Wei L, Zhu J, Zang C, Hu-Li J, Yao Z, Cui K, Kanno Y, Roh TY, Watford WT, Schones DE, Peng W, Sun HW, Paul WE, O'Shea JJ, Zhao K: Global mapping of $\mathrm{H} 3 \mathrm{~K} 4 \mathrm{me} 3$ and $\mathrm{H} 3 \mathrm{~K} 27 \mathrm{me} 3$ reveals specificity and plasticity in lineage fate determination of differentiating CD4+ T cells. Immunity 2009, 30(1):155-167. PubMed PMID: 19144320. Pubmed Central PMCID: 2722509.

26. Hosokawa H, Tanaka T, Kato M, Shinoda K, Tohyama H, Hanazawa A, Tamaki Y, Hirahara K, Yagi R, Sakikawa I, Morita A, Nagira M, Poyurovsky MV, Suzuki Y, Motohashi S, Nakayama T: Gata3/Ruvbl2 complex regulates T helper 2 cell proliferation via repression of Cdkn2c expression. Proc Natl Acad Sci U S A 2013, 110(46):18626-18631. PubMed PMID: 24167278. Pubmed Central PMCID: 3832009

27. Chang S, Aune TM: Dynamic changes in histone-methylation 'marks' across the locus encoding interferon-gamma during the differentiation of T helper type 2 cells. Nat Immunol 2007, 8(7):723-731. PubMed PMID: 17546034.

28. Brand S, Kesper DA, Teich R, Kilic-Niebergall E, Pinkenburg O, Bothur E, Lohoff M, Garn H, Pfefferle PI, Renz H: DNA methylation of TH1/TH2 cytokine genes affects sensitization and progress of experimental asthma. J Allergy Clin Immunol 2012, 129(6):1602-10 e6. PubMed PMID: 22277202

29. Williams CL, Schilling MM, Cho SH, Lee K, Wei M, Aditi, Boothby M: STAT4 and T-bet are required for the plasticity of IFN-gamma expression across Th2 ontogeny and influence changes in Ifng promoter DNA methylation. $\mathrm{J}$ Immunol 2013, 191(2):678-687.

30. Kim ST, Fields PE, Flavell RA: Demethylation of a specific hypersensitive site in the Th2 locus control region. Proc Natl Acad Sci U S A 2007, 104(43):17052-17057. PubMed PMID: 17940027. Pubmed Central PMCID: 2040439.

31. Williams A, Lee GR, Spilianakis CG, Hwang SS, Eisenbarth SC, Flavell RA: Hypersensitive site 6 of the Th2 locus control region is essential for Th2 cytokine expression. Proc Natl Acad Sci U S A 2013, 110(17):6955-6960. PubMed PMID: 23569250. Pubmed Central PMCID: 3637752

32. Pellerin L, Jenks JA, Begin P, Bacchetta R, Nadeau KC: Regulatory T cells and their roles in immune dysregulation and allergy. Immunol Res 2014, 58(2-3):358-368. PubMed PMID: 24781194.
33. Passerini L, de Sio FR S, Roncarolo MG, Bacchetta R: Forkhead box P3: The Peacekeeper of the Immune System. Int Rev Immunol 2013, 33(2):129-145. PubMed PMID: 24354325

34. Zheng Y, Josefowicz S, Chaudhry A, Peng XP, Forbush K, Rudensky AY: Role of conserved non-coding DNA elements in the Foxp3 gene in regulatory T-cell fate. Nature 2010, 463(7282):808-812. PubMed PMID: 20072126. Pubmed Central PMCID: 2884187

35. Kim HP, Leonard WJ: CREB/ATF-dependent T cell receptor-induced FoxP3 gene expression: a role for DNA methylation. J Exp Med 2007, 204 (7):1543-1551. PubMed PMID: 17591856. Pubmed Central PMCID: 2118651.

36. Polansky JK, Kretschmer K, Freyer J, Floess S, Garbe A, Baron U, Olek S, Hamann A, von Boehmer H, Huehn J: DNA methylation controls Foxp3 gene expression. Eur J Immunol 2008, 38(6):1654-1663. PubMed PMID: 18493985.

37. Haiqi $H$, Yong $Z$, Yi L: Transcriptional regulation of Foxp3 in regulatory $T$ cells. Immunobiology 2011, 216(6):678-685. PubMed PMID: 21122941.

38. Ohkura N, Kitagawa Y, Sakaguchi S: Development and maintenance of regulatory T cells. Immunity 2013, 38(3):414-423. PubMed PMID: 23521883

39. Zhang Y, Maksimovic J, Naselli G, Qian J, Chopin M, Blewitt ME, Oshlack A, Harrison LC: Genome-wide DNA methylation analysis identifies hypomethylated genes regulated by FOXP3 in human regulatory T cells. Blood 2013, 122(16):2823-2836. PubMed PMID: 23974203. Pubmed Central PMCID: 3798997.

40. Shevach EM, Thornton AM: tTregs, pTregs, and iTregs: similarities and differences. Immunol Rev 2014, 259(1):88-102. PubMed PMID: 24712461. Pubmed Central PMCID: 3982187

41. Schlenner SM, Weigmann B, Ruan Q, Chen Y, von Boehmer H: Smad3 binding to the foxp3 enhancer is dispensable for the development of regulatory T cells with the exception of the gut. J Exp Med 2012, 209(9):1529-1535. PubMed PMID: 22908322. Pubmed Central PMCID: 3428940.

42. Samstein RM, Josefowicz SZ, Arvey A, Treuting PM, Rudensky AY: Extrathymic generation of regulatory $T$ cells in placental mammals mitigates maternal-fetal conflict. Cell 2012, 150(1):29-38. PubMed PMID: 22770213. Pubmed Central PMCID: 3422629.

43. Lu L, Ma J, Li Z, Lan Q, Chen M, Liu Y, Xia Z, Wang J, Han Y, Shi W, Quesniaux V, Ryffel B, Brand D, Li B, Liu Z, Zheng SG: All-trans retinoic acid promotes TGF-beta-induced Tregs via histone modification but not DNA demethylation on Foxp3 gene locus. PLoS One 2011, 6(9):e24590. PubMed PMID: 21931768. Pubmed Central PMCID: 3172235.

44. Ohkura N, Hamaguchi M, Morikawa H, Sugimura K, Tanaka A, Ito Y, Osaki M, Tanaka Y, Yamashita R, Nakano N, Huehn J, Fehling HJ, Sparwasser T, Nakai K, Sakaguchi S: T cell receptor stimulation-induced epigenetic changes and Foxp3 expression are independent and complementary events required for Treg cell development. Immunity 2012, 37(5):785-799. PubMed PMID: 23123060

45. Palmer LJ, Burton PR, Faux JA, James AL, Musk AW, Cookson WO: Independent inheritance of serum immunoglobulin E concentrations and airway responsiveness. Am J Respir Crit Care Med 2000, 161(6):1836-1843. PubMed PMID: 10852754

46. Cookson W, Moffatt M, Strachan DP: Genetic risks and childhood-onset asthma. J Allergy Clin Immunol 2011, 128(2):266-270. quiz 71-2. PubMed PMID: 21807248

47. Moffatt MF, Gut IG, Demenais F, Strachan DP, Bouzigon E, Heath S, von Mutius E, Farrall M, Lathrop M, Cookson WO, GABRIEL Consortium: A large-scale, consortium-based genomewide association study of asthma. N Engl J Med 2010, 363(13):1211-1221. PubMed PMID: 20860503.

48. Litonjua AA, Carey VJ, Burge HA, Weiss ST, Gold DR: Parental history and the risk for childhood asthma. Does mother confer more risk than father? Am J Respir Crit Care Med 1998, 158(1):176-181. PubMed PMID: 9655726.

49. Cookson WO, Young RP, Sandford AJ, Moffatt MF, Shirakawa T, Sharp PA Faux JA, Julier C, Nakumuura Y: Maternal inheritance of atopic IgE responsiveness on chromosome 11q. Lancet 1992, 340(8816):381-384. PubMed PMID: 1353553.

50. Ruiz RG, Kemeny DM, Price JF: Higher risk of infantile atopic dermatitis from maternal atopy than from paternal atopy. Clin Exp Allergy 1992, 22(8):762-766. PubMed PMID: 1525695.

51. Barrett EG: Maternal influence in the transmission of asthma susceptibility. Pulm Pharmacol Ther 2008, 21(3):474-484. PubMed PMID: 17693106. Pubmed Central PMCID: 2478516. 
52. Rigoli L, Salpietro DC, Lavalle R, Cafiero G, Zuccarello D, Barberi I: Allelic association of gene markers on chromosome 11q in Italian families with atopy. Acta Paediatr 2000, 89(9):1056-1061. PubMed PMID: 11071084.

53. Hill MR, James AL, Faux JA, Ryan G, Hopkin JM, le Souef P, Musk AW, Cookson WO: Fc epsilon Rl-beta polymorphism and risk of atopy in a general population sample. BMJ 1995, 311(7008):776-779. PubMed PMID: 7580438. Pubmed Central PMCID: 2550787.

54. Folsgaard NV, Chawes BL, Rasmussen MA, Bischoff AL, Carson CG, Stokholm J, Pedersen L, Hansel TT, Bønnelykke K, Brix S, Bisgaard H: Neonatal cytokine profile in the airway mucosal lining fluid is skewed by maternal atopy. Am J Respir Crit Care Med 2012, 185(3):275-280. PubMed PMID: 22077068.

55. Hamada K, Suzaki Y, Goldman A, Ning YY, Goldsmith C, Palecanda A, Coull B, Hubeau C, Kobzik L: Allergen-independent maternal transmission of asthma susceptibility. J Immunol 2003, 170(4):1683-1689. PubMed PMID: 12574331

56. Hubeau C, Apostolou I, Kobzik L: Adoptively transferred allergen-specific T cells cause maternal transmission of asthma risk. Am J Pathol 2006, 168 (6):1931-1939. PubMed PMID: 16723708. Pubmed Central PMCID: 1606611

57. Hauk PJ, Forssen A, Pedersen B, Strand M, Munoz L, Schedel M, Lynch A, Winn V, Schwartz DA, Gelfand EW: Differential DNA Methylation In Mothers Increases The Prevalence Of Atopic Dermatitis In Their Offspring. J Allergy Clin Immunol 2014, 133(22):AB149.

58. Zhu J, Adli M, Zou JY, Verstappen G, Coyne M, Zhang X, Durham T, Miri M, Deshpande V, De Jager PL, Bennett DA, Houmard JA, Muoio DM, Onder TT, Camahort R, Cowan CA, Meissner A, Epstein CB, Shoresh N, Bernstein BE: Genome-wide chromatin state transitions associated with developmental and environmental cues. Cell 2013, 152(3):642-654. PubMed PMID: 23333102. Pubmed Central PMCID: 3563935

59. Waterland RA, Jirtle RL: Transposable elements: targets for early nutritional effects on epigenetic gene regulation. Mol Cell Biol 2003, 23(15):5293-5300. PubMed PMID: 12861015. Pubmed Central PMCID: 165709

60. Morgan $\mathrm{HD}$, Sutherland $\mathrm{HG}$, Martin DI, Whitelaw E: Epigenetic inheritance at the agouti locus in the mouse. Nat Genet 1999, 23(3):314-318. PubMed PMID: 10545949.

61. Cropley JE, Dang TH, Martin DI, Suter CM: The penetrance of an epigenetic trait in mice is progressively yet reversibly increased by selection and environment. Proceedings Biological sciences/The Royal Society 2012, 279(1737):2347-2353. PubMed PMID: 22319121. Pubmed Central PMCID: 3350677.

62. Hollingsworth JW, Maruoka S, Boon K, Garantziotis S, Li Z, Tomfohr J, Bailey N, Potts EN, Whitehead G, Brass DM, Schwartz DA: In utero supplementation with methyl donors enhances allergic airway disease in mice. J Clin Invest 2008, 118(10):3462-3469. PubMed PMID: 18802477. Pubmed Central PMCID: 2542847.

63. Li YF, Langholz B, Salam MT, Gilliland FD: Maternal and grandmaternal smoking patterns are associated with early childhood asthma. Chest 2005, 127(4):1232-1241. PubMed PMID: 15821200.

64. Miller LL, Henderson J, Northstone K, Pembrey M, Golding J: Do grandmaternal smoking patterns influence the aetiology of childhood asthma? Chest 2013, Published online Oct 24 2013, PubMed PMID: 24158349.

65. Peters JM, Avol E, Navidi W, London SJ, Gauderman WJ, Lurmann F, Linn WS, Margolis H, Rappaport E, Gong H, Thomas DC: A study of twelve Southern California communities with differing levels and types of air pollution. I Prevalence of respiratory morbidity. Am J Respir Crit Care Med 1999, 159(3):760-767. PubMed PMID: 10051248.

66. Elazab N, Mendy A, Gasana J, Vieira ER, Quizon A, Forno E: Probiotic administration in early life, atopy, and asthma: a meta-analysis of clinical trials. Pediatrics 2013, 132(3):e666-e676. PubMed PMID: 23958764.

67. Runyon RS, Cachola LM, Rajeshuni N, Hunter T, Garcia M, Ahn R, Lurmann F, Krasnow R, Jack LM, Miller RL, Swan GE, Kohli A, Jacobson AC, Nadeau KC: Asthma discordance in twins is linked to epigenetic modifications of $\mathrm{T}$ cells. PLoS One 2012, 7(11):e48796. PubMed PMID: 23226205. Pubmed Central PMCID: 3511472

68. Stefanowicz D, Hackett TL, Garmaroudi FS, Gunther OP, Neumann S, Sutanto EN, Ling KM, Kobor MS, Kicic A, Stick SM, Paré PD, Knight DA: DNA methylation profiles of airway epithelial cells and PBMCs from healthy, atopic and asthmatic children. PLoS One 2012, 7(9):e44213. PubMed PMID: 22970180. Pubmed Central PMCID: 3435400.
69. Soto-Ramirez N, Arshad SH, Holloway JW, Zhang H, Schauberger E, Ewart S, Patil V, Karmaus W: The interaction of genetic variants and DNA methylation of the interleukin- 4 receptor gene increase the risk of asthma at age 18 years. Clinical epigenetics 2013, 5(1):1. PubMed PMID: 23286427. Pubmed Central PMCID: 3544634

70. Breton CV, Byun HM, Wang X, Salam MT, Siegmund K, Gilliland FD: DNA methylation in the arginase-nitric oxide synthase pathway is associated with exhaled nitric oxide in children with asthma. Am J Respir Crit Care Med 2011, 184(2):191-197. PubMed PMID: 21512169. Pubmed Central PMCID: 3172885

71. Morales E, Bustamante M, Vilahur N, Escaramis G, Montfort M, de Cid R, Garcia-Esteban R, Torrent M, Estivill X, Grimalt JO, Sunyer J: DNA hypomethylation at ALOX12 is associated with persistent wheezing in childhood. Am J Respir Crit Care Med 2012, 185(9):937-943. PubMed PMID: 22323304

72. Perera F, Tang WY, Herbstman J, Tang D, Levin L, Miller R, Ho SM: Relation of DNA methylation of $5^{\prime}-\mathrm{CpG}$ island of ACSL3 to transplacental exposure to airborne polycyclic aromatic hydrocarbons and childhood asthma. PLoS One 2009, 4(2):e4488. PubMed PMID: 19221603. Pubmed Central PMCID: 2637989.

73. Fu A, Leaderer BP, Gent JF, Leaderer D, Zhu Y: An environmental epigenetic study of ADRB2 5'-UTR methylation and childhood asthma severity. Clin Exp Allergy 2012, 42(11):1575-1581. PubMed PMID: 22862293. Pubmed Central PMCID: 3673701

74. Luo Y, Zhou B, Zhao M, Tang J, Lu Q: Promoter demethylation contributes to TSLP overexpression in skin lesions of patients with atopic dermatitis. Clin Exp Dermatol 2014, 39(1):48-53. PubMed PMID: 24341479

75. Isidoro-Garcia M, Sanz C, Garcia-Solaesa V, Pascual M, Pescador DB, Lorente F, Dávila I: PTGDR gene in asthma: a functional, genetic, and epigenetic study. Allergy 2011, 66(12):1553-1562. PubMed PMID: 21883277.

76. Pascual M, Suzuki M, Isidoro-Garcia M, Padron J, Turner T, Lorente F, Dávila I, Greally JM: Epigenetic changes in B lymphocytes associated with house dust mite allergic asthma. Epigenetics 2011, 6(9):1131-1137. PubMed PMID: 21975512.

77. Kim YJ, Park SW, Kim TH, Park JS, Cheong HS, Shin HD, Park CS: Genome-wide methylation profiling of the bronchial mucosa of asthmatics: relationship to atopy. BMC medical genetics 2013, 14:39. PubMed PMID: 23521807. Pubmed Central PMCID: 3616917.

78. Breton CV, Byun HM, Wenten M, Pan F, Yang A, Gilliland FD: Prenatal tobacco smoke exposure affects global and gene-specific DNA methylation. Am J Respir Crit Care Med 2009, 180(5):462-467. PubMed PMID: 19498054. Pubmed Central PMCID: 2742762

79. Joubert BR, Haberg SE, Nilsen RM, Wang X, Vollset SE, Murphy SK, Huang Z, Hoyo C, Midttun Ø, Cupul-Uicab LA, Ueland PM, Wu MC, Nystad W, Bell DA, Peddada SD, London SJ: $450 \mathrm{~K}$ epigenome-wide scan identifies differential DNA methylation in newborns related to maternal smoking during pregnancy. Environ Health Perspect 2012, 120(10):1425-1431. PubMed PMID: 22851337. Pubmed Central PMCID: 3491949

80. Reinius LE, Gref A, Saaf A, Acevedo N, Joerink M, Kupczyk M, D'Amato M, Bergström A, Melén E, Scheynius A, Dahlén SE, Pershagen G, Söderhäll C, Kere J, BIOAIR Study Group: DNA methylation in the Neuropeptide S Receptor 1 (NPSR1) promoter in relation to asthma and environmental factors. PLoS One 2013, 8(1):e53877. PubMed PMID: 23372674. Pubmed Central PMCID: 3553086.

81. Slaats GG, Reinius LE, Alm J, Kere J, Scheynius A, Joerink M: DNA methylation levels within the CD14 promoter region are lower in placentas of mothers living on a farm. Allergy 2012, 67(7):895-903. PubMed PMID: 22564189.

82. Michel S, Busato F, Genuneit J, Pekkanen J, Dalphin JC, Riedler J, Mazaleyrat $\mathrm{N}$, Weber J, Karvonen AM, Hirvonen MR, Braun-Fahrländer C, Lauener R, von Mutius E, Kabesch M, Tost J, PASTURE study group: Farm exposure and time trends in early childhood may influence DNA methylation in genes related to asthma and allergy. Allergy 2013, 68(3):355-364. PubMed PMID: 23346934

83. Kohli A, Garcia MA, Miller RL, Maher C, Humblet O, Hammond SK, Nadeau K: Secondhand smoke in combination with ambient air pollution exposure is associated with increasedx $\mathrm{CpG}$ methylation and decreased expression of IFN-gamma in T effector cells and Foxp3 in T regulatory cells in children. Clinical epigenetics 2012, 4(1):17. PubMed PMID: 23009259. Pubmed Central PMCID: 3483214 
84. Rossnerova A, Tulupova E, Tabashidze N, Schmuczerova J, Dostal M, Rossner P Jr, Gmuender H, Sram RJ: Factors affecting the 27K DNA methylation pattern in asthmatic and healthy children from locations with various environments. Mutat Res 2013, 741-742:18-26. PubMed PMID: 23458556.

85. Tang WY, Levin L, Talaska G, Cheung YY, Herbstman J, Tang D, Miller RL, Perera F, Ho SM: Maternal exposure to polycyclic aromatic hydrocarbons and 5'-CpG methylation of interferon-gamma in cord white blood cells. Environ Health Perspect 2012, 120(8):1195-1200. PubMed PMID: 22562770. Pubmed Central PMCID: 3440069.

86. Breton CV, Salam MT, Wang X, Byun HM, Siegmund KD, Gilliland FD: Particulate matter, DNA methylation in nitric oxide synthase, and childhood respiratory disease. Environ Health Perspect 2012, 120(9):1320-1326. PubMed PMID: 22591701. Pubmed Central PMCID: 3440108.

87. Tarantini L, Bonzini M, Apostoli P, Pegoraro V, Bollati V, Marinelli B, Cantone L, Rizzo G, Hou L, Schwartz J, Bertazzi PA, Baccarelli A: Effects of particulate matter on genomic DNA methylation content and iNOS promoter methylation. Environ Health Perspect 2009, 117(2):217-222. PubMed PMID: 19270791. Pubmed Central PMCID: 2649223.

88. Munthe-Kaas MC, Bertelsen RJ, Torjussen TM, Hjorthaug HS, Undlien DE, Lyle R, Gervin K, Granum B, Mowinckel P, Carlsen KH, Carlsen KC: Pet keeping and tobacco exposure influence CD14 methylation in childhood. Pediatr Allergy Immunol 2012, 23(8):747-754. PubMed PMID: 23194293.

89. Naumova AK, Al Tuwaijri A, Morin A, Vaillancourt VT, Madore AM, Berlivet S, Kohan-Ghadr HR, Moussette S, Laprise C: Sex- and age-dependent DNA methylation at the 17q12-q21 locus associated with childhood asthma. Hum Genet 2013, 132(7):811-822. PubMed PMID: 23546690.

90. Munthe-Kaas MC, Torjussen TM, Gervin K, Lodrup Carlsen KC, Carlsen KH, Granum B, Hjorthaug HS, Undlien D, Lyle R: CD14 polymorphisms and serum CD14 levels through childhood: a role for gene methylation? J Allergy Clin Immunol 2010, 125(6):1361-1368. PubMed PMID: 20398919

91. North M, Mah S, Day AG, Kobor M, Ellis AK: Effects Of rs3744262 On DNA Methylation and Symptoms In Participants With Allergic Rhinitis During Grass Pollen Exposure In The Environmental Exposure Unit (EEU). J Allergy Clin Immunol 2014, 133(2):AB89.

92. Ito K, Caramori G, Lim S, Oates T, Chung KF, Barnes PJ, Adcock IM: Expression and activity of histone deacetylases in human asthmatic airways. Am J Respir Crit Care Med 2002, 166(3):392-396. PubMed PMID: 12153977

93. Cosio BG, Mann B, Ito K, Jazrawi E, Barnes PJ, Chung KF, Adcock IM: Histone acetylase and deacetylase activity in alveolar macrophages and blood mononocytes in asthma. Am J Respir Crit Care Med 2004, 170(2):141-147. PubMed PMID: 15087294

94. Su RC, Becker AB, Kozyrskyj AL, Hayglass KT: Altered epigenetic regulation and increasing severity of bronchial hyperresponsiveness in atopic asthmatic children. J Allergy Clin Immunol 2009, 124(5):1116-1118. PubMed PMID: 19895998.

95. Gunawardhana LP, Gibson PG, Simpson JL, Powell H, Baines KJ: Activity and expression of histone acetylases and deacetylases in inflammatory phenotypes of asthma. Clin Exp Allergy 2014, 44(1):47-57. PubMed PMID: 24355018.

96. Cosio BG, Tsaprouni L, Ito K, Jazrawi E, Adcock IM, Barnes PJ: Theophylline restores histone deacetylase activity and steroid responses in COPD macrophages. J Exp Med 2004, 200(5):689-695. PubMed PMID: 15337792. Pubmed Central PMCID: 2212744

97. Su RC, Becker AB, Kozyrskyj AL, Hayglass KT: Epigenetic regulation of established human type 1 versus type 2 cytokine responses. J Allergy Clin Immunol 2008, 121(1):57-63 e3. PubMed PMID: 17980413.

98. Akimova T, Ge G, Golovina T, Mikheeva T, Wang L, Riley JL, Hancock WW Histone/protein deacetylase inhibitors increase suppressive functions of human FOXP3+ Tregs. Clin Immunol 2010, 136(3):348-363. PubMed PMID: 20478744. Pubmed Central PMCID: 2917523.

99. Arpaia N, Campbell C, Fan X, Dikiy S, van der Veeken J, deRoos P, Liu H, Cross JR, Pfeffer K, Coffer PJ, Rudensky AY: Metabolites produced by commensal bacteria promote peripheral regulatory T-cell generation. Nature 2013, 504(7480):451-455. PubMed PMID: 24226773. Pubmed Central PMCID: 3869884

100. Brand S, Teich R, Dicke T, Harb H, Yildirim AO, Tost J, Schneider-Stock R, Waterland RA, Bauer UM, von Mutius E, Garn H, Pfefferle PI, Renz H: Epigenetic regulation in murine offspring as a novel mechanism for transmaternal asthma protection induced by microbes. J Allergy Clin Immunol 2011, 128(3):618-25 e1-7. PubMed PMID: 21680015.

101. Glozak MA, Sengupta N, Zhang X, Seto E: Acetylation and deacetylation of non-histone proteins. Gene 2005, 363:15-23. PubMed PMID: 16289629.

102. Tao R, de Zoeten EF, Ozkaynak E, Chen C, Wang L, Porrett PM, Li B, Turka LA, Olson EN, Greene MI, Wells AD, Hancock WW: Deacetylase inhibition promotes the generation and function of regulatory T cells. Nat Med 2007, 13(11):1299-1307. PubMed PMID: 17922010.

103. Beier UH, Akimova T, Liu Y, Wang L, Hancock WW: Histone/protein deacetylases control Foxp3 expression and the heat shock response of T-regulatory cells. Curr Opin Immunol 2011, 23(5):670-678. PubMed PMID: 21798734. Pubmed Central PMCID: 3190028

104. Kobayashi Y, Bossley C, Gupta A, Akashi K, Tsartsali L, Mercado N, Barnes PJ, Bush A, Ito K: Passive smoking impairs histone deacetylase-2 in children with severe asthma. Chest 2013, 145(2):305-312. PubMed PMID: 24030221

105. Winkler AR, Nocka KN, Williams CM: Smoke exposure of human macrophages reduces HDAC3 activity, resulting in enhanced inflammatory cytokine production. Pulm Pharmacol Ther 2012, 25(4):286-292. PubMed PMID: 22613758.

106. Liu F, Killian JK, Yang M, Walker RL, Hong JA, Zhang M, Davis S, Zhang Y, Hussain M, Xi S, Rao M, Meltzer PA, Schrump DS: Epigenomic alterations and gene expression profiles in respiratory epithelia exposed to cigarette smoke condensate. Oncogene 2010, 29(25):3650-3664. PubMed PMID: 20440268

107. Franco R, Schoneveld O, Georgakilas AG, Panayiotidis MI: Oxidative stress, DNA methylation and carcinogenesis. Cancer Lett 2008, 266(1):6-11. PubMed PMID: 18372104.

108. Baccarelli A, Wright RO, Bollati V, Tarantini L, Litonjua AA, Suh HH, Zanobetti A, Sparrow D, Vokonas PS, Schwartz J: Rapid DNA methylation changes after exposure to traffic particles. Am J Respir Crit Care Med 2009, 179 (7):572-578. PubMed PMID: 19136372. Pubmed Central PMCID: 2720123.

109. Bollati V, Baccarelli A, Hou L, Bonzini M, Fustinoni S, Cavallo D, Byun HM, Jiang J, Marinelli B, Pesatori AC, Bertazzi PA, Yang AS: Changes in DNA methylation patterns in subjects exposed to low-dose benzene. Cancer Res 2007, 67(3):876-880. PubMed PMID: 17283117

110. Bekkers MB, Elstgeest LE, Scholtens S, Haveman-Nies A, de Jongste JC, Kerkhof M, Koppelman GH, Gehring U, Smit HA, Wijga AH: Maternal use of folic acid supplements during pregnancy, and childhood respiratory health and atopy. Eur Respir J 2012, 39(6):1468-1474. PubMed PMID: 22034647.

111. Martinussen MP, Risnes KR, Jacobsen GW, Bracken MB: Folic acid supplementation in early pregnancy and asthma in children aged 6 years. Am J Obstet Gynecol 2012, 206(1):72 e1-7. PubMed PMID: 21982024. Pubmed Central PMCID: 3246127.

112. Binkley KE, Leaver C, Ray JG: Antenatal risk factors for peanut allergy in children. Allergy, asthma, and clinical immunology : official journal of the Canadian Society of Allergy and. Clin Immunol 2011, 7:17.

113. Li-Weber M, Giaisi M, Treiber MK, Krammer PH: Vitamin E inhibits IL-4 gene expression in peripheral blood T cells. Eur J Immunol 2002 32(9):2401-2408. PubMed PMID: 12207324.

114. McKeever TM, Lewis SA, Smit H, Burney P, Britton J, Cassano PA: Serum nutrient markers and skin prick testing using data from the Third National Health and Nutrition Examination Survey. J Allergy Clin Immunol 2004, 114(6):1398-1402. PubMed PMID: 15577844.

115. Sato $Y$, Akiyama $H$, Suganuma $H$, Watanabe $T$, Nagaoka $M H$, Inakuma T, Goda Y, Maitani T: The feeding of beta-carotene down-regulates serum IgE levels and inhibits the type I allergic response in mice. Biol Pharm Bull 2004, 27(7):978-984. PubMed PMID: 15256726.

116. Hoppu U, Rinne M, Salo-Vaananen P, Lampi AM, Piironen V, Isolauri E: Vitamin $C$ in breast milk may reduce the risk of atopy in the infant. Eur J Clin Nutr 2005, 59(1):123-128. PubMed PMID: 15340369.

\section{doi:10.1186/1710-1492-10-27}

Cite this article as: Bégin and Nadeau: Epigenetic regulation of asthma and allergic disease. Allergy, Asthma \& Clinical Immunology 2014 10:27. 